\title{
Hatay İlinde Karma Yem ve Hammadde İşletmelerinin Sosyo-Demografik Yapısı
}

Bilgin SIKAR 1 , Tülay ÇIMRIN²

Hatay Mustafa Kemal Üniversitesi Ziraat Fakültesi Zootekni Bölümü, Hatay, ${ }^{1}$ https://orcid.org/0000-0002-9313-4248, ${ }^{2}$ https://orcid.org/0000-0002-5868-4148,

$\bowtie$ : tcimrin@hotmail.com

\section{ÖZET}

Çalışmada Hatay ilinde bulunan karma yem ve hammadde üreten işletmelerin sosyo-demografik yapısı araştırılmıştır. Bu amaçla, 8'i hammadde, 3’ü karma yem fabrikası olmak üzere toplam 11 adet işletme ile yüz yüze görüşme yöntemiyle anket çalışması yapılmıştır. Veriler, \% hesaplamalar ve frekans tabloları ile özetlenerek değerlendirilmiştir. Elde edilen bulgulara göre hammadde üreten işletme sahiplerinin \% 25’i ilköğretim, \% 37.5’nin ise lise ve üniversite mezunu oldukları, yaş ve deneyim yılı ortalamalarının sırasıyla 47.9 ve 19.1 olduğu belirlenmiştir. Karma yem işletmesi sahipleri, \% 33.3'lük oranda ilköğretim, lise ve üniversite mezunu olup, yaş ve deneyim yılı ortalamaları sırasıyla 51.7 ve 31.7 'i olarak belirlenmiştir. Hammadde üreten işletmelerin büyük bir kısmında, karma yem işletmelerinin ise tamamında müdür bulunduğu saptanmıştır. Hammadde üreten işletmelerin sadece \% 25'inde teknik eleman varken, karma yem işletmelerinin tamamında teknik eleman olduğu, ayrıca gelişmiş ülkelere göre oldukça fazla işçi çalıştırdıkları belirlenmiştir. Hammadde ve karma yem işletmelerinin sırasıyla kapasite kullanım oranları (KKO) \% 58.8 ve \% 42.3 olarak hesaplanmıştır. Sonuç olarak, ilde faaliyet gösteren karma yem ve hammadde işletme sahiplerinin, hammaddelerin kalitesi, temini, üretimi, karma yemin kalitesi ve kontrolü yönünde işbirliği içerisinde olmaları ve bu alanda eğitim almaları sektörün gelişmesini hızlandıracaktır. Ayrıca ildeki eski ve çoğunluğu yarı otomatik işletmelerin, devlet ya da hibe desteklerle revize edilerek tam otomatik işletmelere dönüştürülmesi, KKO'nın artmasına, daha az işgücü ile daha fazla üretimin daha ucuza yapılmasına ve dolayısıyla hayvansal üretimin gelişmesine katkı sağlayacaktır.

\section{Socio-Demographic Structure of Compound Feed and Feedstuffs Industry in Hatay Province}

\section{ABSTRACT}

In this study, socio-demographic structure of compound feed and feedstuffs enterprises in Hatay province was investigated. For this purpose, a total of 11 enterprises, 8 of feedstuffs and 3 of compound feed factories, were surveyed. The data were summarized with \% calculations and frequency tables. It was determined that $25 \%$ of the feedstuffs enterprises were graduates from primary school, $37.5 \%$ were high school and university. The average age and experience years were determined as 47.9 and 19.1, respectively. Compound feed business owners were evenly primary, high school and university graduates at a rate of $33.3 \%$, and the average age and experience years were determined as 51.7 and 31.7 , respectively. It was found that the majority of the feedstuffs enterprises and the compound feed enterprises owned the managers. Overall, $25 \%$ of the feedstuffs enterprises and $100 \%$ of compound feed enterprises employed the technical staff. It has been determined that all feed enterprises in the province operate as semi-automatic system and employ a lot of workers compared to developed countries. Capacity utilization rates of feedstuffs and compound feed mill enterprises were calculated as $58.8 \%$ and $42.3 \%$, respectively. As a result, the cooperation of the feed
Araştırma Makalesi

Makale Tarihçesi

Geliş Tarihi : 27.12.2019

Kabul Tarihi : 09.04.2020

Anahtar Kelimeler

Eğitim durumu

Hatay

Teknik eleman

Yem endüstrisi
Research Article
$\begin{array}{ll}\text { Article History } \\ \text { Received } \quad: 27.12 .2019 \\ \text { Accepted } \quad: 09.04 .2020\end{array}$

\section{Keywords}

Education Level

Hatay

Technical staff

Feed industry 
and feedstuffs business owners operating in the province in terms of quality, supply, production, quality and control of mixed feed and training in this field will accelerate the development process of the sector. In addition, the conversion of old and mostly semi-automatic enterprises in the province to fully automatic enterprises by means of state or grant supports will increase the capacity utilization rates, enable less production with less labor and thus will contribute to the development of animal production.

To Cite : Sıkar B, Çimrin T 2020. Hatay İlinde Karma Yem ve Hammadde İşletmelerinin Sosyo-Demografik Yapısı. KSÜ Tarım ve Doğa Derg 23 (4): 1096-1105. DOI: 10.18016/ksutarimdoga.vi.666269.

\section{GIRIŞ}

İnsanlarda beslenme bilinci ve gelir düzeyinin artması, hayvansal ürünlere olan talebi artırırken beraberinde karma yem ve yem hammaddelerine olan talebin de artmasını sağlamıştır. Hayvansal üretimde ve yem sektöründe meydana gelen bu ihtiyacin karşılanabilmesi, sürdürebilirliğinin sağlanması, öncelikli olarak eldeki mevcut kaynaklardan en etkin şekilde yararlanılması ile mümkün görünmektedir. Ayrıca hayvansal üretimi artırmada amaç, hayvan sayısını artırmaktan çok, hayvan başına elde edilecek ürün miktarını artırmaktır (Anıç, 2006). Bu nedenle hayvansal üretim yapan işletmeler bir taraftan yüksek verimli hayvanları tercih ederken, diğer yandan bu hayvanların genetik kapasitelerinin elverdiği ölçüde verim almayı ve bunu en düşük maliyetli yemle elde etmeyi hedeflemektedirler. Dolayısıyla hayvansal üretimde kârlılığı artırmak, hayvanların fizyolojik durumları ile verilecek yem maddelerinin yapısı arasındaki ekonomik dengenin kurulmasına bağlıdır (Karakuş, 2016). Hayvancıllk işletmelerinde yem gideri hayvan türlerine göre farklılık göstermekle birlikte işletmelerin üretim maliyetinin yaklaşı \% 6075'ini oluşturmaktadır (Akdeniz ve ark., 2005; Alçiçek ve Yurtman, 2009). Dolayısıyla yüksek yem maliyetine rağmen düşük kaliteli yem ve yetersiz ürün elde edilmesi hayvansal üretimin artmasinı sinırlandırmaktadır (Karabulut ve ark., 2000; Karahocagil ve Ege, 2004). Başka bir ifadeyle hayvancılığın gelişmesi ve üretimin artırılması karma yem sanayi ile yakından ilgilidir (Demir ve Aral, 2009). Bunun yanında üreticinin gelirinin sinırlı olması ve besleme konusundaki yetersizlik hayvansal üretimdeki verim artışını olumsuz etkilemektedir (Kaygisız ve Tümer, 2009). Karma yem sanayisindeki teknolojik gelişmeler ile karma yemlerin yem değerlerinde önemli artışlar olabileceğini ifade eden Akbay ve Ak (2018), bunun yanı sira yem maliyetlerinde düşme ve sürdürülebilir üretimin devamlılığının söz konusu olabileceğini belirtmişlerdir. Gülsün ve Miç (2018), bazı hedef programlama modelleri kullanılarak rasyon hazırlama yöntemiyle yem maliyetinin düşürülebileceğini ifade etmiştir. Yine Oruç ve Çolak (2019) Bulanık Analitik Hiyerarşi Prosesi (BAHP) yöntemi kullanarak en ideal yemi seçebilme ve optimum verimi elde edebilmenin mümkün olabileceğini ifade etmişlerdir. Karakuş (2016), yem masraflarının azaltılması, buna karşılık verimin arttırılması için karma yemlerin üretimi aşamasında farklı verim artırıcı maddelerin (vitaminler, mineraller, antioksidan maddeler vb.) kullanıldığını bildirmiştir. Ancak karma yem üreten bazı işletmeler bu katkı maddeleri konusunda yeterli bilgiye sahip değildir. Nitekim Budağ ve Keçeci (2013), yaptıkları çalışmada Van ilinde bulunan bazı besicilerin eğitim seviyelerinin düşük olduğunu, rasyonlarını kendilerinin hazırladıklarını, hayvan besleme ve yemler konusunda eğitim almaları gerektiğini belirtmişlerdir. Dolayısıyla yem sektöründe olan kişilerin, teknolojiyi, hammadde ve katkı maddeleri konusundaki güncel gelişmeleri takip edebilecek düzeyde eğitim seviyesine sahip olması bu sektörün gelişmesine önemli katkılar sağlayacaktır. Bu kapsamda çalışma; Hatay il ve ilçelerde bulunan kurulu karma yem ve hammadde işletme sahiplerinin sosyo-demografik yapısının belirlenmesi amaciyla yürütülmüştür Ayrıca çalışma gelecekte yapılacak yeni çalışmalara kaynak oluşturabilmesi açısından önemli olabilir.

\section{MATERYAL ve YÖNTEM}

Çalışmanın ana materyalini, Hatay ilinde faaliyet gösteren karma yem ve yem hammaddesi üreten işletmelerden yüz yüze yapılan anket yöntemiyle elde edilen veriler oluşturmuş̧ur. $\mathrm{Bu}$ kapsamda ilde faaliyet gösteren 3'ü karma yem, 8'i hammadde üretimi yapan, toplam 11 adet işletme ile anket yapılmıştır. Anketlerin hazırlanmasında ve anket yapılacak işletmelerin belirlenmesinde, Hatay İ Tarım ve Orman Müdürlüğü Gıda Yem Şubesi kayıtlarından alınan bilgiler (Fabrika sayısı, adres bilgileri), konu ile ilgili önceden yapılmış çalışmalar, raporlar, Antakya Ticaret ve Sanayi Odası gibi kuruluşlardan temin edilen verilerden yararlanılmıştır.

Anket yapılacak işletmelerin belirlenmesinde işletme sayısı az olduğu için tam sayım yöntemi kullanılmıştır. Hatay ilinde bulunan faal durumdaki fabrikaların tamamı ziyaret edilmiştir. Çalışmada Hatay ilinde faal durumda bulunan yem ve hammadde işletme sahiplerinin ve çalışanlarının eğitim durumları, yaşı, meslekteki deneyim durumları, teknik personel ve 
işgücü durumları, mülkiyet durumları kurulu ve kullanılan kapasite durumları sorularak verdikleri cevaplar değerlendirilmiştir. Çalışmanın planlandığı aşamada Hatay İl Tarım ve Orman Müdürlüğü Gıda Yem Şubesi kayıtlarına göre Hatay ilinde 5'i karma yem, 16'sı yem hammaddesi üreten toplam 21 adet işletme faal durumda iken, anketlerin uygulanmaya başlandığı dönemde çeşitli sebeplerle 1 adet karma yem, 3 adet yem hammaddesi üreten işletme kapanmıştır. Ayrıca Hatay İ Tarım ve Orman Müdürlüğü Gıda Yem Şubesi kayıtlarına göre 2 ayrı işletme olarak kabul edilen işletmenin aslında aynı firmaya ait olduğu belirlenmiş ve tek anket uygulanmıştır. Dolayısıyla yem hammaddesi üreten işletme sayısı 15'e düşmüştür. Geriye kalan 1 adet karma yem ve 4 adet hammadde üreten işletme ankete katılmak istememiştir. Ankete katılmak istemeyen işletmelerin 2 adeti gerekçe göstermeden uygulamaya katılmazken, diğerlerinin gerekçesi, yönetim tarafindan izin verilmediği yönünde olmuştur. $\mathrm{Bu}$ nedenle, anket çalışması 3 adet karma yem, 8 adet yem hammaddesi üreten işletme ile gerçekleştirilmiştir. Sonuç olarak faal olan işletmeler arasında ankete katılım oranı, karma yem işletmeleri için \% 75 , yem hammaddesi üreten işletmeler için \% 66.66 olarak gerçekleşmiştir. Verilerin analizinde frekans tabloları ve $\%$ hesaplamalardan faydalanılmıştır.

\section{BULGULAR VE TARTIŞMA}

İşletme sahiplerinin eğitim durumları, yaşı ve deneyim süreleri

Hatay ili anket çalışması yapılan 11 adet işletmede işletme tipine göre firma sahibinin eğitim durumu, yaşı ve meslekteki deneyim sürelerine ait bilgiler Çizelge 1'de verilmiştir. Hammadde işletme sahiplerinin \% 25’i ilköğretim, \% 37.5’i lise ve üniversite seviyesinde eğitim aldıkları belirlenmiştir. Karma yem işletme sahiplerinin eğitim durumları ise ilköğretim, lise ve üniversite arasında eşit bir dağılım göstermiştir. Yem hammaddesi üreten işletmecilerin \% 25'i 20-40 yaş grubu aralığında yer alırken, bu yaş aralığında karma yem üreten işletmeci bulunmamaktadır. Her iki işletme tipinde de işletmecilerin \% 60'dan fazlasının 41-60 yaş aralığında olduğu, işletmecilerin yaş ortalamasının hammadde işletmelerinde $47.9 \mathrm{yll}$, karma yem işletmelerinde ise 51.7 yll olduğu belirlenmiştir. İşletmecilerin deneyim yılı ortalaması hammadde işletmelerinde 19.1 yıl, karma yem işletmelerinde ise 31.7 yıl olarak belirlenmiştir. Karma yem işletme sahiplerinin hammadde işletmecilerine göre daha fazla deneyime sahip olduğu belirlenmiştir. Dolayısıyla işletme sahiplerinin yaş ve deneyim süreleri arasında bir bağlantı olduğu ve orta yaşlı neslin üretimi devam ettirdiği söylenebilir.

Çizelge 1. İşletme tipine göre işletme sahibinin eğitim durumu, yaşı ve deneyimi

Table 1. According to business type the, of enterprises owner's education level, age and experience

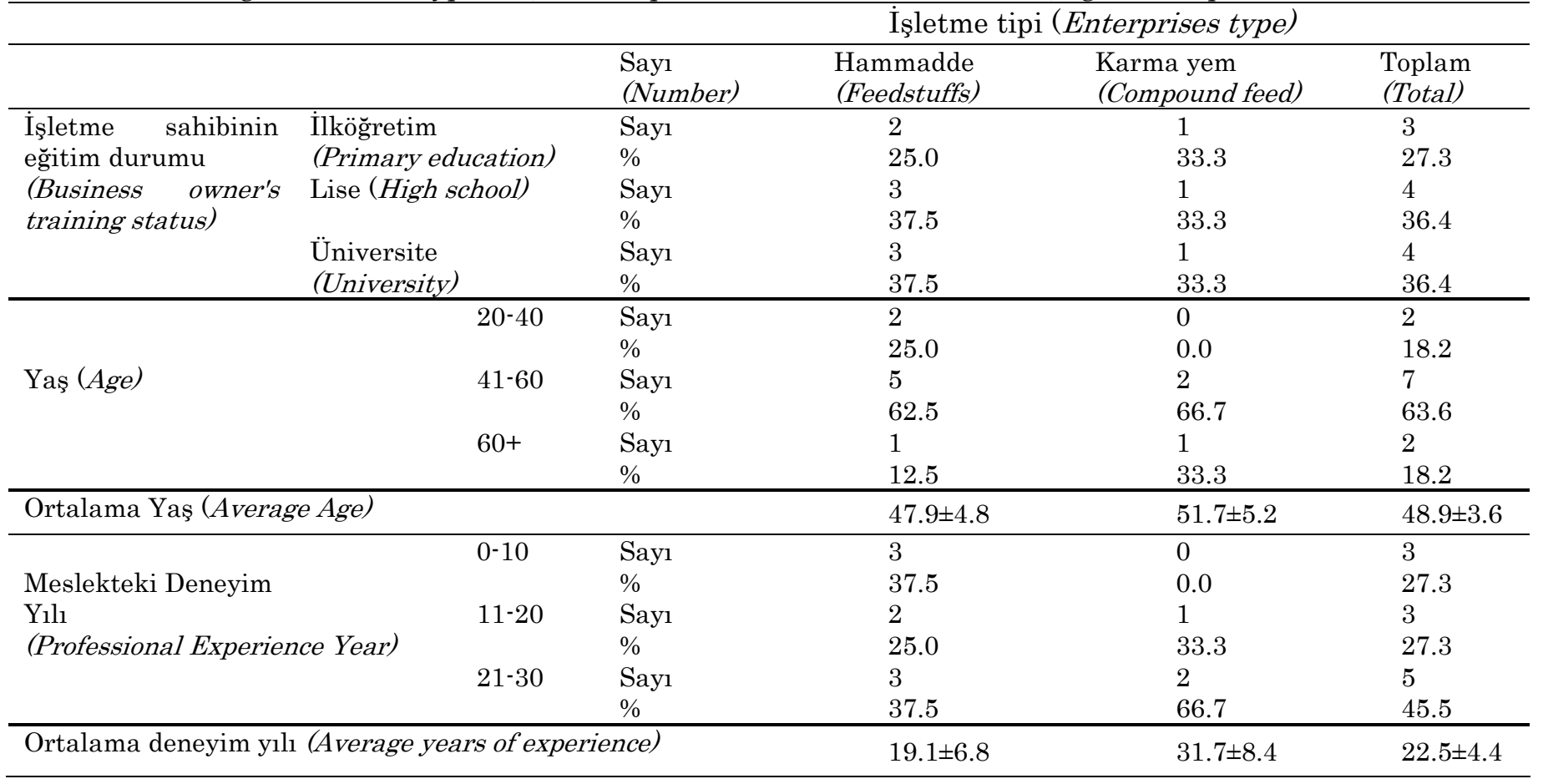

İşletmelerde çalışanların eğitim durumları, yaşı ve deneyimleri

İşletmelerin tipine göre işletmede müdür çalıştırma durumu, müdür varsa eğitimi ve yaş durumuna ait bilgiler Çizelge 2'de verilmiştir. İşletmelerin \% 72.7'sinde işletme müdürü varken, \% 27.3’ünde 
bulunmamaktadır. Hammadde üreten işletmelerde ayrıca bir müdür bulunmamakla birlikte işletme sahibi müdürün görevini üstlenen kişi durumundadır. $\mathrm{Bu}$ çalışmadaki hammadde işletmelerinin yönetim yapısına benzer şekilde Diyarbakır ilinde bulunan yem fabrikalarında müdür olarak çalışan 10 kişinin aynı zamanda işyeri sahibi olduğu da belirlenmiştir (Denli ve ark., 2015). Ancak Hatay ilindeki karma yem üretim işletmelerinde durum biraz farklıdır. Bu ildeki tüm karma yem işletmeleri müdür çalıştırdığı gibi müdürlerin tamamının üniversite mezunu olduğu belirlenmiştir. Yem hammaddesi üreten işletmelerde ise müdürlerin önemli bir bölümü ilköğretim seviyesinde eğitime sahiptir. Müdürlerin aynı zamanda işletme sahibi olması, aslında işletmelerin düşük kapasiteli ve mümkün olduğu ölçüde az personel çalıştırma eğiliminde olduklarını göstermektedir. Başka bir ifadeyle işletmeler büyüdükçe ilköğretim mezunlarının oranında azalma, üniversite mezunlarının oranında ise artış olduğu söylenebilir. İşletme tiplerine göre yaş gruplandırması yapılan müdürlerin hammadde işletmelerinde \% 80’i 41-60 yaş aralığında ve yaş ortalamasinın 47.2 yıl olduğu, karma yem üreten işletmelerinde ise 20-40 yaş aralığında ve yaş ortalamasının 36 yıl olduğu belirlenmiştir. Hammadde üreten işletmelerin müdürlerinin önemli bir bölümünün daha yaşlı oldukları görülmektedir.

Çizelge 2. İşletmelerin tipine göre, müdür varlığı, eğitim durumu ve yaşı

Table 2. According to the type of enterprises, the presence of the manager, educational status and age

\begin{tabular}{|c|c|c|c|c|c|}
\hline & & & İşletn & terprises type) & \\
\hline & & $\begin{array}{l}\text { Sayı } \\
\text { (Number) }\end{array}$ & $\begin{array}{l}\text { Hammadde } \\
\text { (Feedstuffs) }\end{array}$ & $\begin{array}{l}\text { Karma yem } \\
\text { (Compound feed) }\end{array}$ & $\begin{array}{l}\text { Toplam } \\
\text { (Total) }\end{array}$ \\
\hline İşletme müdür & $\operatorname{Var}($ Exist $)$ & Sayı & 5 & 3 & 8 \\
\hline Varlığ̀ & & $\%$ & 62.5 & 100.0 & 72.7 \\
\hline (Presence of business & Yok $(N o)$ & Sayı & 3 & 0 & 3 \\
\hline manager) & & $\%$ & 37.5 & 0.0 & 27.3 \\
\hline Eğitim durumu & İlköğretim & Sayı & 3 & 0 & 3 \\
\hline (Education Level) & $\begin{array}{l}\text { (Primary } \\
\text { education) }\end{array}$ & $\%$ & 60.0 & 0.0 & 37.5 \\
\hline & Üniversite & Sayı & 2 & 3 & 5 \\
\hline & (University) & $\%$ & 40.0 & 100.0 & 62.5 \\
\hline Yaş (Age) & $20-40$ & Sayı & 1 & 2 & 3 \\
\hline & & $\%$ & 20.0 & 66.7 & 37.5 \\
\hline & $41-60$ & Sayı & 4 & 1 & 5 \\
\hline & & $\%$ & 80.0 & 33.3 & 62.5 \\
\hline Yaş ortalamaları (yıl) ( & rage age) (yc & & $47.2 \pm 5.0$ & $36.0 \pm 4.6$ & $43.0 \pm 3.9$ \\
\hline
\end{tabular}

İşletmelerin tipine göre işletme müdürlerinin deneyim yılına ait bilgiler Çizelge 3'de verilmiştir. Hammadde üreten işletmelerin müdürlerinin \% 60'ı 21-30 yıl aralığında deneyime sahip olduğu ve deneyim yılı ortalamasının 22.4 yıl olduğu belirlenmiştir. Oysa karma yem üreten işletmelerde bu durum tam tersidir. Yani müdürlerin \% 66.7’i 1-10 yıl aralığında deneyime sahiptir ve ortalama deneyim süresi 10.6 yıldır. Bu durumda hammadde üreten işletme müdürlerinin daha yaşlı ve tecrübeli oldukları söylenebilir.

İşletme tiplerine göre işletmede müdürlerin çalışma süreleri değerlendirildiğinde, hammadde üreten işletmelerde \% 20'si 1-10 yıl, \% 40'1 11-20 yıl ve geriye kalan \% 40'nın ise 20-30 yıl aynı işletmede çalıştıkları tespit edilmiştir. Karma yem üreten işletmelerde çalışan işletme müdürlerinin ise \% 66.7'sinin 1-10 yıl, \% 33.3'ünün ise 11-20 yıl aynı işletmede çalıştıkları saptanmıştır. Bu sonuçlar işletme sahiplerinin uzun yıllar aynı müdürlerle çalışmayı tercih ettiklerini, akrabalık, dostluk ilişkilerinin henüz bozulmadığını ya da yeterince başarılı olduklarını göstermektedir. Hatay ilinin küçük bir il olması nedeniyle, iş ilişkilerinde profesyonellikten ziyade aile ve akrabalık ilişkilerinin ön planda olduğu gözlemlenmiştir. Tekerli (2010), Ege Bölgesi'nde 41 adet yem fabrikası ile yaptıkları çalışmada teknik hizmetlerde $\% \quad 60$ oranında ziraat mühendisi, \% 40 düzeyinde ise veteriner hekim istihdam edildiğini bildirmiştir. Yine aynı çalışmada, fabrika yöneticisi bazında ise \% 70 ziraat mühendisi, \% 19.5 veteriner hekim ve \% 9.5 diğer branşlardan personel çalıştırıldığını bildirmiştir. Hatay ilindeki hammadde ve karma yem işletmelerinde olduğu gibi Ege Bölgesi’nde faaliyet gösteren tüm fabrikalarında personellerini yakın çevredeki yerlerden sağladıkları rapor edilmiştir. Işletmelerin tipine göre işletme müdürlerinin mezun oldukları ön lisans ve-lisans bölümüne ait bilgiler Çizelge 4'de verilmiştir. İşletme müdürlerin meslekleri incelendiğinde hammadde üreten işletme müdürlerinin çevre ve makine mühendisliği bölümlerinden mezun oldukları belirlenirken, karma yem üreten işletme müdürlerinin \% 66.7'i ziraat mühendisliği kalan kısmı ise muhasebe bölümlerinden mezun oldukları belirlenmiştir. İşletme sahipleri müdür tercihlerinde, meslekten ziyade aileye yakınlık 
ve başarıyı dikkate aldıklarını ifade etmişlerdir.

Çizelge 3. İşletmelerin tipine göre müdürün meslekteki deneyimleri ve işletmedeki çalışma süreleri

Table 3. According to the type of enterprises, the manager's professional experience and working time in the enterprise

\begin{tabular}{|c|c|c|c|c|c|}
\hline & & \multicolumn{4}{|c|}{ İşletme tipi (Enterprises type) } \\
\hline & & $\begin{array}{l}\text { Sayı } \\
\text { Number }\end{array}$ & $\begin{array}{l}\text { Hammadde } \\
\text { Feedstuffs }\end{array}$ & $\begin{array}{l}\text { Karma yem } \\
\text { Compound feed }\end{array}$ & $\begin{array}{l}\text { Toplam } \\
\text { Total }\end{array}$ \\
\hline \multirow{6}{*}{$\begin{array}{l}\text { Müdürün Deneyim Yılı } \\
\text { (Manager Experience year) }\end{array}$} & $1-10$ & Sayı & 1 & 2 & 3 \\
\hline & & $\%$ & 20.0 & 66.7 & 37.5 \\
\hline & $11-20$ & Sayı & 1 & 1 & 2 \\
\hline & & $\%$ & 20.0 & 33.3 & 25.0 \\
\hline & $21-30$ & Sayı & 3 & 0 & 3 \\
\hline & & $\%$ & 60.0 & 0.0 & 37.5 \\
\hline \multicolumn{3}{|c|}{ Ortalama Deneyim Yll (Average years of experience) } & $22.4 \pm 4.3$ & $10.6 \pm 4.1$ & $18.0 \pm 3.6$ \\
\hline \multirow{6}{*}{$\begin{array}{l}\text { Müdürlerin İşletmelerdeki Çalışma Yılı } \\
\text { (Working Year of Managers in Enterprises) }\end{array}$} & $1-10$ & Sayı & 1 & 2 & 3 \\
\hline & & $\%$ & 20.0 & 66.7 & 37.5 \\
\hline & $11-20$ & Sayı & 2 & 1 & 3 \\
\hline & & $\%$ & 40.0 & 33.3 & 37.5 \\
\hline & $21-30$ & Sayı & 2 & 0 & 2 \\
\hline & & $\%$ & 40.0 & 0.0 & 25.0 \\
\hline \multicolumn{2}{|l|}{ Ortalama çalışma yılı (Average working year) } & & $17.0 \pm 3.2$ & $10.7 \pm 4.1$ & $14.6 \pm 2.6$ \\
\hline
\end{tabular}

Çizelge 4. İşletmelerin tipine göre, işletme müdürlerinin mezun olduğu bölümler

Table 4. According to the type of enterprises, departments where business managers graduate

\begin{tabular}{|c|c|c|c|c|}
\hline & & \multicolumn{3}{|c|}{ İşletme tipi (Enterprises type) } \\
\hline $\begin{array}{l}\text { Müdürlerin mezun olduğu bölümler } \\
\text { Departments where managers graduated }\end{array}$ & $\begin{array}{l}\text { Sayı } \\
\text { (Number) }\end{array}$ & $\begin{array}{l}\text { Hammadde } \\
\text { (Feedstuffs) }\end{array}$ & $\begin{array}{l}\text { Karma yem } \\
\text { (Compound feed) }\end{array}$ & $\begin{array}{l}\text { Toplam } \\
\text { (Total) }\end{array}$ \\
\hline Çevre mühendisliği (Environmental engineering) & $\begin{array}{l}\text { Sayı } \\
\%\end{array}$ & $\begin{array}{l}1 \\
50.0\end{array}$ & 0 & $\begin{array}{l}1 \\
20.0\end{array}$ \\
\hline Makine mühendisliği (Mechanical engineering) & $\begin{array}{l}\text { Sayı } \\
\%\end{array}$ & $\begin{array}{l}1 \\
50.0\end{array}$ & $\begin{array}{l}0 \\
0.0\end{array}$ & $\begin{array}{l}1 \\
20.0\end{array}$ \\
\hline Muhasebe bölümü (Accounting department) & $\begin{array}{l}\text { Sayı } \\
\%\end{array}$ & $\begin{array}{l}0 \\
0.0\end{array}$ & $\begin{array}{l}1 \\
33.3\end{array}$ & $\begin{array}{l}1 \\
20.0\end{array}$ \\
\hline Ziraat mühendisliği (Agriculture Engineering) & $\begin{array}{l}\text { Sayl } \\
\%\end{array}$ & $\begin{array}{l}0 \\
0.0\end{array}$ & $\begin{array}{l}2 \\
66.7 \\
\end{array}$ & $\begin{array}{l}2 \\
40.0 \\
\end{array}$ \\
\hline
\end{tabular}

İşletmelerin tipine göre işletmelerde teknik eleman çalıştırma durumlarına ait veriler Çizelge 5'de verilmiştir. Buna göre hammadde üreten işletmelerin $\%$ 25'inde teknik eleman varken, karma yem işletmelerinin hepsinde teknik eleman bulunmaktadır. Her iki işletme tipinde çalışan teknik elemanların tamamının üniversite mezunu olduğu belirlenmiştir. Hammadde işletmelerinde çalışan teknik elemanların tümü 20-40 yaş aralığında ve yaş ortalaması 28.5 yıl olup, deneyim yılı ortalaması 3.5 yıl ve işletmedeki çalışma yılı ortalaması da 3.5 yıl olarak belirlenmiştir. Karma yem işletmelerinde ise \% 66.7'si 20-40 yaş, \% 33.3'ü 41-60 yaş aralığında olup yaş ortalaması $33.6 \mathrm{yll}$, deneyim yılı ortalaması 7 yıl ve işletmedeki çalışma yılı ortalaması da 6.3 yıl olarak hesaplanmıştır.

İşletmelerin tipine göre işletmelerde teknik elemanların mezun olduğu bölümlere ait bilgiler Çizelge 6'da verilmiştir. Hammadde işletmelerinde sadece iki adet teknik eleman olup, biri kimya, diğeri gıda mühendisidir. Karma yem işletmelerinde çalışan teknik elemanların tümü ise ziraat mühendisidir. İşletmeler büyüdükçe, hem idari ve teknik kadrolarda çalışan personel oranında hem de üniversite mezunlarının oranlarında artma görülürken, işletmeler küçüldükçe bu oranlarda azalma görülmüştür.

İşletmelerin tipine göre işletmelerde daimi, geçici ve toplam iş̧̧i kullanımına ilişkin elde edilen sonuçlar Çizelge 7'de sunulmuştur. Hammadde işletmeleri toplam işçi sayısı bakımından değerlendirildiğinde işletmelerin \% 12.5'i 1-10 adet, \% 50'si 11-20 adet ve \% 37.5 'i 20 adetten fazla iş̧̧i çalıştırmaktadır. Türkiye'de yem fabrikalarının çoğu yarı otomatik sistemle faaliyet göstermektedir ve dolayısıyla işçi sayısı fazla olmaktadır. Oysa teknolojik olarak gelişmiş ülkelerde yem fabrikaları çoğunlukla tam otomatik sistemlerle ve ortalama 5 iş̧̧i ile üretim faaliyeti göstermektedir (Bayraktar, 1999). Bu çalışmada, faal olan 8 hammadde işletmesinde toplam 290 adet işçinin 
çalıştı̆̆g , bunun 201 adetinin daimi, 89 adetinin ise geçici işçi olduğu tespit edilmiştir. Geçici iş̧̧ilerin işletmelerde üretimin arttığı dönemlerde işe alınıp, üretimin azaldığı dönemlerde işten çıkartıldıkları belirlenmiştir. Faal olan 3 karma yem işletmesinde ise 32 adet iş̧̧i daimi olarak çalışmaktadır. Hammadde ve karma yem üreten işletmelerde toplam iş̧̧i sayı ortalamaları sirasiyla 32.3 ve 10.7 olarak hesaplanmıştır. Budağ (2011), Van ilinde yem fabrikalarında çalışan eleman sayıları ortalamasını 16.2 kişi olarak belirlemiştir. Bu sayı Hatay ilindeki hammadde işletmelerinde çalışan eleman sayısına göre düşük, karma yem işletmelerinde çalışan eleman sayısına göre daha yüksek bulunmuştur. Bu değerler açısından Hatay ili gelişmiş ülkelerle kıyaslandığında, hammadde işletmeleri için yaklaşık 7 , karma yem için ise 2 kattan fazla işçi çalıştırıldığı görülmektedir. Bu durum işletme sistemlerinin eski ve çoğunluğunun yarı otomatik olmasıyla ilişkilendirilebilir. İşletmelerde tam otomatikleşme sağlanabilirse, insan gücüne olan ihtiyaç azalacağından yem maliyetinde düşme ve dolayısıyla kârlılık oranında artışa neden olabilir.

Çizelge 5. İşletmelerin tipine göre, işletmede teknik eleman varlığ 1

Table 5. According to the type of enterprises, the presence of technical staff in the enterprise

\begin{tabular}{|c|c|c|c|c|c|}
\hline & & & & i (Enterprises typ & \\
\hline & & $\begin{array}{l}\text { Sayı } \\
\text { (Number) }\end{array}$ & $\begin{array}{l}\text { Hammadde } \\
\text { Feedstuffs }\end{array}$ & $\begin{array}{l}\text { Karma yem } \\
\text { (Compound feed) }\end{array}$ & $\begin{array}{l}\text { Toplam } \\
\text { (Total) }\end{array}$ \\
\hline Teknik eleman varlığ & Var (Üniversite) & Sayı & 2 & 3 & 5 \\
\hline (Presence of technical & Exist (University) & $\%$ & 25.0 & 100.0 & 45.5 \\
\hline staff) & Yok $(N o)$ & Sayı & 6 & 0 & \\
\hline & & $\%$ & 75.0 & 0.0 & 54.5 \\
\hline Yaş aralığı (Age range) & $20-40$ & Sayı & 2 & 2 & 4 \\
\hline & & $\%$ & 100.0 & 66.7 & 80.0 \\
\hline & $41-60$ & Sayı & 0 & 1 & 1 \\
\hline & & $\%$ & & 33.3 & 20.0 \\
\hline Yaş ortalaması (yıl) (Ave & age age (years)) & & $28.5 \pm 4.5$ & $33.6 \pm 4.7$ & $31.6 \pm 3.6$ \\
\hline Ortalama Deneyim Yılı & Average years of exl & ience) & $3.5 \pm 1.5$ & $7.0 \pm 3.0$ & $5.6 \pm 1.9$ \\
\hline $\begin{array}{l}\text { İşletmelerde ortalama ça } \\
\text { (Average working time }\end{array}$ & $\begin{array}{l}\text { 1şma süresi } \\
\text { enterprises) }\end{array}$ & & $3.5 \pm 1.5$ & $6.3 \pm 3.4$ & $5.2 \pm 2.0$ \\
\hline
\end{tabular}

Çizelge 6. İşletmelerin tipine göre, teknik elemanların mezun olduğu bölümler

Table 6. According to the type of enterprises, technical staff graduates

\begin{tabular}{llccc}
\hline & \multicolumn{4}{c}{ İşletme tipi (Enterprises type) } \\
\hline Teknik elemanların bölümleri & $\begin{array}{l}\text { Sayı } \\
\text { Technical staff graduates }\end{array}$ & $\begin{array}{l}\text { Hammadde } \\
\text { (Number) }\end{array}$ & $\begin{array}{c}\text { Karma yem } \\
\text { (Compound feed) }\end{array}$ & $\begin{array}{c}\text { Toplam } \\
\text { (Total) }\end{array}$ \\
\hline Kimya Mühendisliği (Chemical Engineering) & Sayı & 1 & 0 & 1 \\
& $\%$ & 50.0 & 0.0 & 20.0 \\
Gida Mühendisliği (Food Engineering) & Sayı & 1 & 0 & 1 \\
& $\%$ & 50.0 & 0.0 & 20.0 \\
Ziraat Mühendisliği (Agriculture Engineering) & Sayı & 0 & 3 & 3 \\
& $\%$ & 0.0 & 100.0 & 40.0 \\
\hline
\end{tabular}

İşletmelerin tipine göre işletmelerde uygulanan günlük vardiya sayısına ilişkin elde edilen sonuçlar Çizelge 8'de sunulmuştur. Hammadde işletmelerinin büyük çoğunluğunda vardiya sayısı birden fazladır. Oysa karma yem işletmelerinin \% 66.7'inde tek vardiya ile üretim yapılmaktadır. İldeki işletme sahipleri, üretim kapasitelerinin yanı sıra, yem talebinin de düşük olması nedeniyle, ikili ya da üçlü vardiya sistemiyle çalışmaya ihtiyaç olmadığını belirtmişlerdir. Ancak nem ve isı dengeli yeni sistem yem depolarına sahip oldukları takdirde kullanım kapasitelerini ve dolayısıyla vardiya sayılarını artırma yoluna giderek, yem hammadde fiyatlarının düştüğü dönemlerde daha fazla üretim yapabileceklerini ifade etmişlerdir.
İşletmelerin kuruluş yllı ve mülkiyet durumları

İşletmelerin tipine göre işletmelerin kuruluş yıllarına ilişkin elde edilen sonuçlar Çizelge 9'da sunulmuştur. Buna göre hammadde işletmelerinin yarısı 2000 yılı öncesi yarısı da 2000 yılı sonrasında kurulmuştur. Karma yem işletmelerinin ise büyük çoğunluğunun 2000 yılı öncesi kurulduğu belirlenmiştir.

İşletmelerin tipine göre işletmelerin mülkiyet durumlarına ilişkin elde edilen sonuçlar Çizelge 10'da sunulmuştur. Hammadde üreticilerinin \% 87.5’i kendi mülklerinde \% 12.5 ' $\mathrm{i}$ ise kiralanmış işletmelerde faaliyet göstermektedirler. Karma yem işletmelerinin büyük çoğunluğunun kendi işletmelerinde üretim 
yaptıkları belirlenmiştir.

Çizelge 7. İşletmelerin tipine göre, işletmelerde işgücü kullanım durumları

Table 7. According to the type of enterprises, labor use status in enterprises

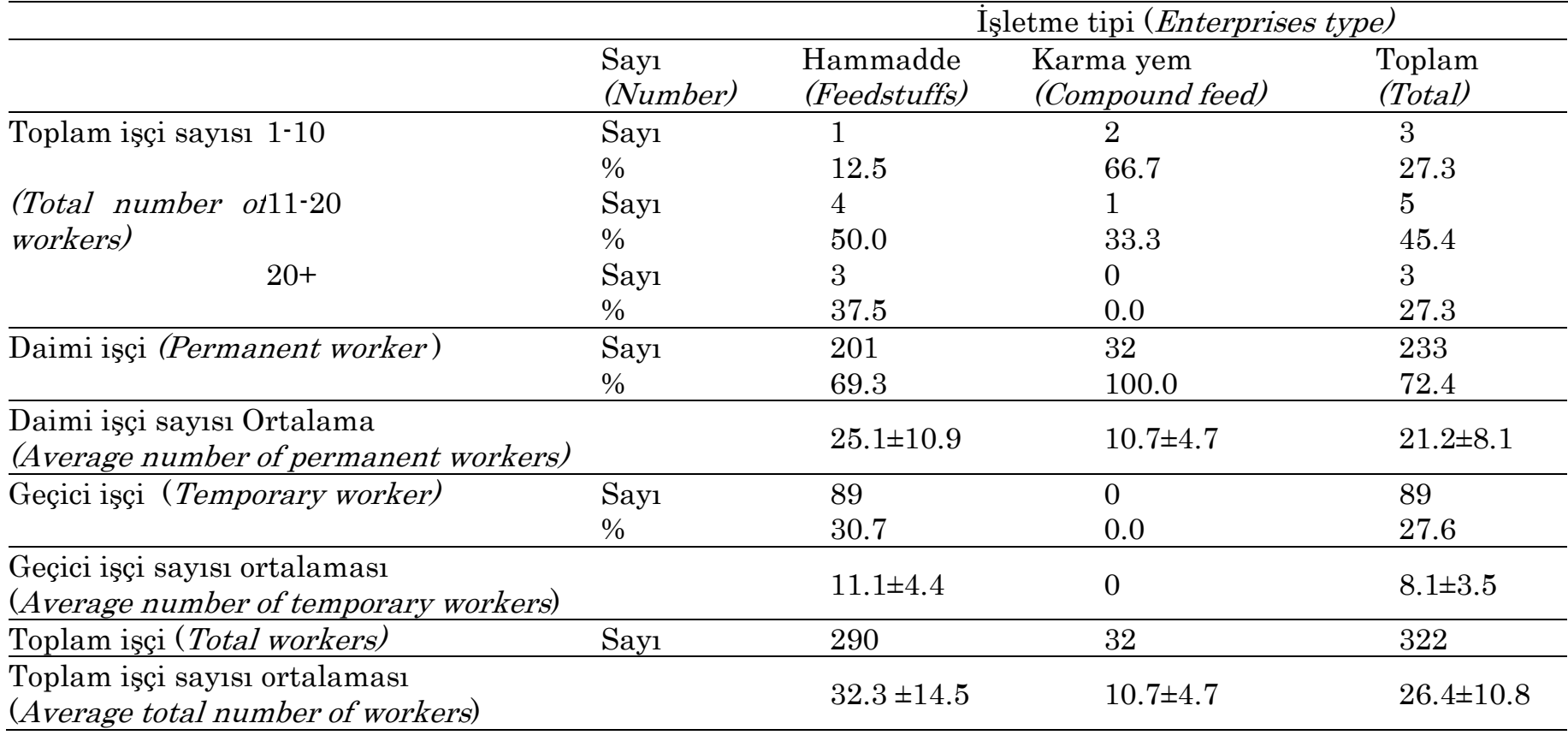

Çizelge 8. İşletmelerin tiplerine göre, işletmelerde günlük vardiya sayıları

Table 8. According to the type of enterprises, number of daily shifts in enterprises

\begin{tabular}{lccccc}
\hline & & \multicolumn{3}{c}{ İsletme tipi (Enterprises type) } \\
\hline & & $\begin{array}{c}\text { Sayı } \\
\text { (Number) }\end{array}$ & $\begin{array}{c}\text { Hammadde } \\
\text { (Feedstuffs) }\end{array}$ & $\begin{array}{l}\text { Karma yem } \\
\text { (Compound feed) }\end{array}$ & $\begin{array}{l}\text { Toplam } \\
\text { (Total) }\end{array}$ \\
\hline Günlük Vardiya Sayısı & 1.00 & Sayı & 1 & 2 & 3 \\
(Daily Shifts) & & $\%$ & 12.5 & 66.7 & 27.3 \\
& \multirow{2}{*}{2.00} & Sayı & 3 & 1 & 4 \\
& & $\%$ & 37.5 & 33.3 & 36.4 \\
& \multirow{2}{*}{3.00} & Sayı & 4 & 0 & 4 \\
& & $\%$ & 50.0 & 0.0 & 36.4 \\
\hline
\end{tabular}

Çizelge 9. İşletmelerin tipine göre, işletmelerin kuruluş yılı dönemleri

Table 9. According to the type of enterprises, the establishment year periods of enterprises

İşletmenin kuruluş yılı (Year of establishment)

\begin{tabular}{llccc}
\hline & $\begin{array}{l}\text { Sayl } \\
\text { (Number) }\end{array}$ & $\begin{array}{c}\text { Hammadde } \\
\text { (Feedstuffs) }\end{array}$ & $\begin{array}{c}\text { Karma yem } \\
\text { (Compound feed) }\end{array}$ & $\begin{array}{c}\text { Toplam } \\
\text { (Total) }\end{array}$ \\
\hline 2000 öncesi (Before 2000) & Say1 & 4 & 2 & 6 \\
& $\%$ & 50.0 & 66.7 & 54.5 \\
2000 sonrasi (After 2000) & Sayl & 4 & 1 & 5 \\
& $\%$ & 50.0 & 33.3 & 45.5 \\
\hline
\end{tabular}

Çizelge 10. İşletmelerin tiplerine göre, işletmelerin mülkiyet durumları

Table 10. According to the types of enterprises, ownership status of enterprises

\begin{tabular}{lllccc}
\hline & \multicolumn{4}{c}{ İsletme tipi (Enterprises type) } \\
\hline & & $\begin{array}{l}\text { Sayı } \\
\text { (Number) }\end{array}$ & $\begin{array}{c}\text { Hammadde } \\
\text { (Feedstuffs) }\end{array}$ & $\begin{array}{c}\text { Karma yem } \\
\text { (Compound feed) }\end{array}$ & $\begin{array}{c}\text { Toplam } \\
\text { (Total) }\end{array}$ \\
\hline Issletme mülk mü? & Evet (Yes) & Sayı & 7 & 2 & 9 \\
(Is the property property?) & & $\%$ & 87.5 & 66.7 & 81.8 \\
& \multirow{2}{*}{ Hayır (No) } & Sayı & 1 & 1 & 2 \\
& & $\%$ & 12.5 & 33.3 & 18.2 \\
\hline
\end{tabular}


İşletme tiplerine göre kurulu ve kullanılan kapasite durumları

İşletmelerin tipine ve gruplara göre işletmelerin kurulu kapasite durumlarına ilişkin elde edilen sonuçlar Çizelge 11'de ve Çizelge 12'de sunulmuştur.

Hammadde isletmelerinin \% 37.5'i ylda $1-10.000$ ton arası, \% 25’i 10.001-20.000 ton arası ve kalan \% 37.5’i de 20.000 tonun üzerinde üretim kapasitesine sahiptir. Karma yem işletmelerinin ise \% 66.7'si 1-10.000 ton arası ve \% 33.3 'ü ise 20.000 tonun üzerinde üretim yapabilme kapasitesi üzerine kurulmuştur. Çizelge 12'de görüldüğü gibi hammadde üreten işletmelerde mevcut ylllı kurulu kapasite 278.910 ton iken, kullanılan kapasitesinin 163.960 ton düzeyinde olduğu, 114.950 ton kapasitenin kullanılmadığı ve KKO'ının \% 58.8 olduğu belirlenmiştir. Karma yem işletmelerinde ise kurulu kapasitenin yılda 184.000 on, kullanılan kapasitenin 77.820 ton, kullanılmayan kapasitenin 106.180 ton ve KKO'ının \% 42.3 olduğu belirlenmiştir. Denli ve ark. (2015)'ı tarafından yapılan çalışmada, Diyarbakır'daki yem fabrikalarının mevcut yıllık kurulu kapasiteleri 388.800 ton iken, faal durumda olan yem fabrikalarmin 230.400 ton düzeyinde üretim yaptıkları, yaklaşık olarak 158.400 ton yem kapasitenin ise kullanılmadığ ve faal durumdaki yem fabrikalarının KKO'ının \% 50.3 olduğu bildirilmiştir. Diyarbakır ilinde faal olan yem fabrikalarının KKO'nın (\% 50.3) Hatay ilindeki hammadde işletmelerinin KKO'nından (\% 58.8) düşük, karma yem işletmelerinin KKO'nından (\% 42.3) yüksek olduğu görülmektedir. Hatay ilinde karma yem işletmelerinde KKO'nın düşük olmasının nedenleri arasında, anket çalışmasının yapıldığ yılları arasında yem fiyatlarının ve dolar kurunun yüksek olması, karma yeme olan talebin düşük olması büyük işletmeler hariç, genellikle ekstansif besleme yapan küçük işletmelerde bu tip beslemeye elverişli düşük verimli yerli irk veya melez irkların tercih edilmesi olabilir. Hatay ili hammadde üreten işletmeler için belirlenen \% 58.8 KKO’ı Diyarbakır (\% 50.3) ve Doğu Anadolu Bölgesi'nin KKO'nından (\% 44.64) yüksek bulunmuştur (Denli ve ark., 2015; Demir ve Aksu Elmall, 2011). Ancak Hatay karma yem işletmelerinde durum tam tersi olup KKO'ı (\% 42.3), hem Diyarbakır hem de Doğu Anadolu Bölgesi için belirlenen değerlerden düşük bulunmuştur. Demir ve

Cizelge 11. İşletmelerin tiplerine ve gruplandırmalara göre, kurulu kapasite durumları

Table 11. According to the types and groupings of enterprises, installed capacity states

\begin{tabular}{llccc}
\hline & & \multicolumn{2}{c}{ İsletme tipi (Enterprises type) } \\
\hline $\begin{array}{l}\text { Kurulu kapasite (ton yll) } \\
\text { Installed capacity (ton year) }\end{array}$ & $\begin{array}{l}\text { Sayı } \\
\text { (Number) }\end{array}$ & $\begin{array}{l}\text { Hammadde } \\
\text { (FeedstuffS) }\end{array}$ & $\begin{array}{c}\text { Karma yem } \\
\text { (Compound feed) }\end{array}$ & $\begin{array}{l}\text { Toplam } \\
\text { (Total) }\end{array}$ \\
\hline $1-10000$ & Sayı & 3 & 2 & 5 \\
& $\%$ & 37.5 & 66.7 & 45.5 \\
$10001-20000$ & Sayı & 2 & 0 & 2 \\
& $\%$ & 25.0 & 0.0 & 18.2 \\
$20000+$ & Sayı & 3 & 1 & 4 \\
& $\%$ & 37.5 & 33.3 & 36.4 \\
\hline
\end{tabular}

Cizelge 12. Hatay ilindeki işletmelerin kurulu kapasite, kullanılan kapasite ve kapasite kullanım oranları Table 12. Installed capacity, capacity and capacity utilization rates of enterprises in Hatay

\begin{tabular}{lccc}
\hline $\begin{array}{l}\text { İsletme tipi (Enterprises type) } \\
\text { Hammadde (Feedstuffs) }\end{array}$ & $\begin{array}{c}\text { Kurulu kapasite (ton) } \\
\text { (Installed capacity) }\end{array}$ & $\begin{array}{c}\text { Kullanilan kapasite(ton) } \\
\text { (Capacity used) }\end{array}$ & $\begin{array}{c}\text { KKO (\%) } \\
\text { (Capacity Utilization Rates) }\end{array}$ \\
\hline 1 & 54750 & 30000 & 54.8 \\
2 & 10000 & 10000 & 100 \\
3 & 20000 & 7000 & 35 \\
4 & 1000 & 800 & 80 \\
5 & 65000 & 36000 & 55 \\
6 & 8160 & 8160 & 350 \\
7 & 20000 & 7000 & 65 \\
8 & 100000 & 65000 & 58.8 \\
\hline Toplam (Total) & 278910 & 163960 & 100 \\
\hline Karma yem (Compound feed) & & & 37.5 \\
1 & 7200 & 7200 & 40 \\
2 & 4000 & 1500 & 42.3 \\
3 & 172800 & 69120 & \\
\hline Toplam (Total) & 184000 & 77820 & \\
\hline
\end{tabular}


Aksu Elmalı (2011), Doğu Anadolu'daki yem fabrikalarının KKO’nın düşük olmasının nedeninin \% 62.50 oranında talep yetersizliğinden kaynaklandığını tespit etmişlerdir.

İşletme tiplerine göre kalifiye eleman durumuna ilişkin elde edilen sonuçlar Çizelge 13'de sunulmuştur. Hammadde işletmelerinin \% 75’i kalifiye eleman bulma konusunda sıkıntısı yaşamadıklarını ifade ederken, \% 25'i zaman zaman bu konuda büyük sıkıntı yaşadıklarını belirtmişlerdir.

Karma yem işletmelerinde ise durum tam tersi olup işletmelerin büyük bir kısmının kalifiye eleman bulma konusunda sıkıntıları olduğunu ifade etmişlerdir. Benzer şekilde Tekerli (2010), Ege bölgesindeki yem fabrikalarının kalifiye işgücü bulmakta zorlandıklarını rapor etmiştir.

Çizelge 13. İşletmelerin tiplerine göre, kalifiye eleman temin durumları

Table 13. According to the types of enterprises, the availability of qualified personnel

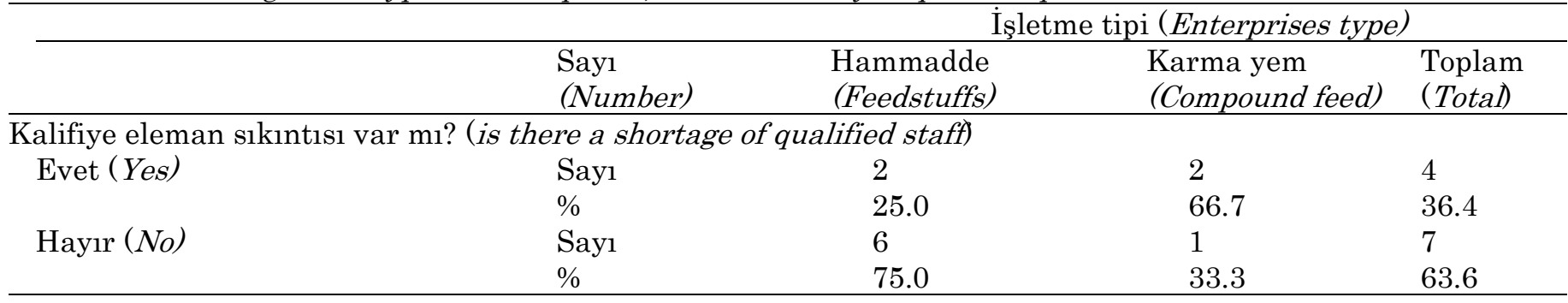

\section{SONUÇ ve ÖNERILER}

Sonuç olarak hem hammadde hem de karma yem işletme sahipleri arasında ilköğretim, lise ve üniversite mezunlarının olduğu ve oransal olarak benzerlik gösterdiği belirlenmiştir. Karma yem işletme sahipleri hammadde üreten işletme sahiplerine göre daha yaşlı ve daha fazla deneyime sahip oldukları tespit edilmiştir. Yem hammaddesi üreten işletmelerin büyük bir kısmında ilköğretim seviyesinde eğitime sahip müdür olduğu ve bu müdürlerin çoğunun aynı zamanda işletme sahibi olduğu belirlenmiştir. Oysa karma yem işletmelerinin hepsinin üniversite mezunu olan müdür çalıştırdığı saptanmıştır.

Günümüzde teknoloji kullanımı ve son gelişmeleri takip edebilmek adına eğitim seviyesinin yüksek olması işletmelere önemli katkılar sağlayabilir. Bu konuda karma yem işletmelerinin avantajlı olduğu söylenebilir. Müdürlerin işe alınırken, onların mesleklerinden ziyade aileye yakınlık ve başarı öykülerinin dikkate aldıkları tespit edilmiştir.

Hammadde üreten işletme müdürlerinin karma yem işletme müdürlerine göre daha yaşlı ve daha tecrübeli olduğu belirlenmiştir. Hammadde işletmelerinin büyük bir kısmında teknik eleman olmadığı, karma yem işletmelerinin ise hepsinde teknik eleman çalıştırıldığı belirlenmiştir. İşletmelerde çalışan işçi sayısının gelişmiş ülkelere göre fazla olduğu belirlenmiştir. Hammadde üreten işletmelerde günlük vardiya sayısının daha fazla ve KKO'ının daha yüksek olduğu belirlenmiştir. İşletmelerin büyük bir kısmının kendi mülklerinde faaliyet gösterdikleri saptanmıştır. Karma yem işletmeleri hammadde işletmelerinden daha fazla kalifiye eleman sıkıntısı yaşadığı tespit edilmiştir. Sonuç olarak, ilgili kurumlarca, ilde faaliyet gösteren karma yem ve hammadde işletme sahiplerine, Tarım ve Orman Bakanlığı'nın açıkladığı gıda ve yem hizmetleri listesinde yer alan, yem maddeleri ve yem katkı maddeleri konusunda eğitici seminerler verilebilir. Böylece hammadde ve yem katkı maddelerinin kullanımı hakkında güncellenen bilgiler ışı̆̆ında kaynaklarının rasyonel kullanımı sağlanarak, daha düşük maliyetle daha kaliteli yem üretimi gerçekleştirilebilir. Dolayısıyla hayvancılık sektöründe ana maliyeti yem masrafinın oluşturduğu düşünülürse daha ucuza kaliteli yem temini hayvancılığın gelişmesine katkı sağlayabilir.

\section{TEŞEKKÜR}

Tülay Çimrin yönetiminde tamamlanan Yüksek Lisans çalışmasının bir kısmı olup, yazarlar çalışmaya maddi destek sağlayan Hatay Mustafa Kemal Üniversitesi Bilimsel Araştırma Projeleri Kurum Koordinatörlüğü'ne (BAP: Proje No: 15563) teşekkür ederler.

\section{Çıkar Çatışması Beyanı}

Makale yazarları aralarında herhangi bir çıkar çatışması olmadığını beyan ederler.

\section{Araştırmacıların Katkı Oranı Beyan Özeti}

Yazarlar makaleye eşit oranda katkı sağlamış olduklarını beyan ederler.

\section{KAYNAKLAR}

Akbay KC, Ak İ 2018. Karma Yem Teknolojisindeki Gelişmelerin Karma Yem Kalitesine ve Yem Değerine Etkileri. Bursa Uludağ Üniversitesi Ziraat Fakültesi Dergisi 32(2): 175-188.

Akdeniz RC, Ak İ, Boyar S 2005. Türkiye Karma Yem 
Endüstrisi ve Sorunları. VI. Türkiye Ziraat Mühendisliği Teknik Kongresi. TMMOB Ziraat Mühendisleri Odası (ZMO) Cilt:2: 935-959, 03-07 Ocak, Ankara.

Alçiçek A, Yurtman Y 2009. Entansif Koyunculukta Besleme. U. Ü. Ziraat Fakültesi Dergisi 23(2): 1-13.

Anıç HŞ 2006. Trakya Bölgesindeki Yem Fabrikalarının Hammadde Temini ve Pazarlama Sorunları Üzerine Bir Araştırma. Trakya Üniversitesi Fen Bilimleri Enstitüsü Tarım Ekonomisi ABD Yüksek Lisans Tezi, $62 \mathrm{~s}$.

Bayraktar F 1999. Yem Sektörü, Türkiye Kalkınma Bankası A.S., Sektörel Araştırmalar, Ankara SA 99-2-8 TKB matbaasi.

Budağ C 2011. Van'da Bulunan Yem Fabrikalarının Üretim Durumları ve Sorunları. YYÜ. Fen Bilimleri Enstitüsü Dergisi 16(2): 59-66.

Budağ C, Keçeci Ş 2013. Van'da Büyükbaş Hayvan Besilerinde Kullanılan Yemler ve Besi Şekillerine İlişkin Bir Anket Calışması. Yüzüncü Yıl Üniversitesi Fen Bilimleri Enstitüsü Dergisi 18(12):48-6.

Demir P, Aksu Elmalı D 2011. Doğu Anadolu Bölgesindeki Kimi Yem Fabrikalarının Mevcut Durumu ve Sorunları. Veteriner Hekimler Derneği Dergisi 82(1): 29-34.

Demir P, Aral S 2009. Kars İlinde Faaliyet Gösteren Süt Sığırcılık İşletmelerinin Karşılaştıkları Sorunlar ve Çözüm Önerileri. Veteriner Hekimler Derneği Dergisi 88(3): 17-22.

Denli M, Demirel R, Sessiz A 2015. Diyarbakır İli
Karma Yem Endüstrisinin Durumu. Türk Tarım Gida Bilim ve Teknoloji Dergisi 3(9): 701-706.

Gülsün B, Miç P 2018. Rasyon Hazırlamada Temel Yem Miktarlarının Ekonomik Olarak Belirlenmesi İçin Çok Amaçlı Programlama Yaklaşımı. ÖHÜ Müh. Bilim. Dergisi 7(2): 634-648.

Karabulut A, Ergül M, Ak İ, Kutlu HR, Alçiçek A 2000. Karma Yem Endüstrisi. V. Türkiye Ziraat Mühendisliği Teknik Kongresi, TMMOB Ziraat Mühendisleri Odası (ZMO) 2: 985-1008, 17-21 Ocak, Ankara.

Karahocagil P, Ege H 2004. Karma Yem Sanayi. Tarımsal Ekonomi Araştırma Enstitüsü. T.E.A.EBakış 5(9): 1-4.

Karakuş MÜ 2016. Türkiye'de Karma Yem Üretimi ve Sorunlar1. www.zmo.org.tr/resimler/ekler/aa903e40952a84b_ ek.pdf. (Erişim Tarihi: 13.06.2018).

Kaygisız A, Tümer R 2009. Kahramanmaraş İli Süt Siğgrrcılığı İşletmelerinin Yapısal Özellikleri: 3. Hayvan Besleme Alışkanlıkları. KSÜ Doğa Bil. Dergisi 12(1): 48-52.

Oruç KO, Çolak M 2019. Bulanık Analitik Hiyerarşi Prosesi Yöntemi ile Yem Seçimi. Süleyman Demirel Üniversitesi Vizyoner Dergisi 10(25): 495-510.

Tekerli N 2010. Ege Bölgesi Karma Yem Sanayinin Mevcut Durumunun İncelenmesi ve Geliştirilmesi Üzerine Bir Araştırma. Namık Kemal Üniversitesi Fen Bilimleri Enstitüsü Zootekni ABD Dalı Yüksek Lisans Tezi, 55 sy. 